\title{
Classification of Leafy Spurge With Earth Observing-1 Advanced Land Imager
}

\author{
Susan Stitt, ${ }^{1}$ Ralph Root, ${ }^{2}$ Karl Brown, ${ }^{3}$ Steve Hager, ${ }^{4}$ \\ Carol Mladinich, ${ }^{1}$ Gerald L. Anderson, ${ }^{5}$ Kathleen Dudek, ${ }^{6}$ \\ Monica Ruiz Bustos, ${ }^{7}$ and Raymond Kokaly ${ }^{8}$

\begin{abstract}
Authors are ${ }^{1}$ Physical Scientist, ${ }^{2}$ Physical Scientist (deceased), US Geological Survey, Rocky Mountain Geographic Science Center, Denver, CO 80225-0046; ${ }^{3}$ Program Analyst, US Geological Survey, Center for Biological Informatics, Denver, CO 80225; ${ }^{4}$ GIS Specialist, National Park Service, Theodore Roosevelt National Park, Medora, ND 58645-0007; ${ }^{5}$ Research Ecologist, US Department of Agriculture, Agricultural Research Service, Northern Plains Agricultural Research Laboratory, Sidney, MT 59270; ${ }^{6}$ Graduate Student, Colorado State University, College of Forest Sciences, Fort Collins, CO 80523; ${ }^{7}$ Fulbright Scholar from Spanish Ministry of Public Works, US Geological Survey, Rocky Mountain Geographic Science Center, Denver, CO 80225;

${ }^{8}$ Research Geophysicist, US Geological Survey, Spectroscopy Laboratory, Denver, CO 80225.
\end{abstract}

\begin{abstract}
Leafy spurge (Euphorbia esula L.) is an invasive exotic plant that can completely displace native plant communities. Automated techniques for monitoring the location and extent of leafy spurge, especially if available on a seasonal basis, could add greatly to the effectiveness of control measures. As part of a larger study including multiple sensors, this study examines the utility of mapping the location and extent of leafy spurge in Theodore Roosevelt National Park using Earth Observing-1 satellite Advanced Land Imager (ALI) scanner data. An unsupervised classification methodology was used producing accuracies in the range of $59 \%$ to $66 \%$. Existing field studies, with their associated limitations, were used for identifying class membership and accuracy assessment. This sensor could be useful for broad landscape scale mapping of leafy spurge, from which control measures could be based.
\end{abstract}

\section{Resumen}

El euforbio de montaña (Euphorbia esula L.) es una planta invasora exótica que puede desplazar completamente a las comunidades de plantas naturales. Técnicas automatizadas para monitorear la ubicación y extensión del euforbio de montaña, especialmente si están disponibles estacionalmente, podrían mejorar mucho la eficacia de medidas de control. Como parte de un estudio mas amplio que incluye múltiples sensores, este análisis examina la utilidad de cartografiar la ubicación y la extensión del euforbio de montaña en el Parque Nacional Teodoro Roosevelt utilizando el datos obtenidos por el satélite Earth Observing1 advanced land imager (ALI). Las imágenes fueron analizadas con una metodología de clasificación no supervisada y la precisión final se encontró entre $59 \%$ y $66 \%$. Estudios de campo existentes, con sus limitaciones respectivas, fueron utilizados para identificar la asociación de clases y evaluar la precisión. Este sensor podría ser útil para la cartografía a grandes escalas del paisaje del euforbio de montaña, con lo que se podrían establecer medidas de control.

Key Words: Euphorbia esula, invasive species, noxious weeds, remote sensing

\section{INTRODUCTION}

Theodore Roosevelt National Park has a mission to preserve and protect the natural resources within its borders for the enjoyment of the public and future generations. Leafy spurge (Euphorbia esula L.) is an exotic plant that invades native plant communities, and can completely displace them (Andrascik 1994; Lym and Zollinger 1995). It destroys the rich species

Research was funded in part by the USDA Agricultural Research Service.

The use of firm, trade, and brand names in this report is for identification purposes only and does not constitute endorsement by the US Geological Survey.

At the time of the research, the senior author was Biologist, US Geological Survey, Center for Biological Informatics, Denver, C0.

Correspondence: Susan Stitt, US Geological Survey, Rocky Mountain Geographic Science Center, PO Box 25046, MS 516, Denver, C0 80225-0046. Email: susan_ stitt@usgs.gov

Manuscript received 11 April 2006; manuscript accepted 14 July 2006. diversity unique to the badlands ecosystem (Cogan and Butler 1999) by forming extensive monocultures, with root systems that can be 15 or more feet deep. Seeds can remain viable for up to 8 years (Lym et al. 1998). It produces milky latex that is poisonous to some animals, and is not eaten by buffalo, elk, deer, or cattle. Nonindigenous species damage and control efforts cost the United States approximately $\$ 137$ billion per year during the 1990s (Pimentel et al. 2000). If one considers nonindigenous weeds only, they cost US agriculture about $\$ 27$ billion per year, plus the loss of forage, and the cost of herbicides are estimated at another $\$ 6$ billion each year (Mack et al. 2000; Pimentel et al. 2000). Leafy spurge alone is estimated to cost more than $\$ 144$ million a year in production losses, control expenses, and other impacts in Wyoming, Montana, and the Dakotas (Merritt et al. 2000). Critical to Theodore Roosevelt National Park is the loss of valuable grasslands, reducing the habitat and food source of native wildlife (Andrascik 1994; National Park Service 1994). Exotic plant management has 
Table 1. E0-1 ALI spectral coverage.

\begin{tabular}{llcc}
\hline Band no. & $\begin{array}{c}\text { Band } \\
\text { description }\end{array}$ & Wavelength $(\mu \mathrm{m})$ & $\begin{array}{c}\text { Ground sample } \\
\text { distance }(\mathrm{m})\end{array}$ \\
\hline 1 & MS-1* & $0.433-0.453$ & 30 \\
2 & MS-1 & $0.45-0.515$ & 30 \\
3 & MS-2 & $0.525-0.605$ & 30 \\
4 & MS-3 & $0.63-0.69$ & 30 \\
5 & MS-4 & $0.775-0.805$ & 30 \\
6 & MS-4* & $0.845-0.89$ & 30 \\
7 & MS-5* & $1.2-1.3$ & 30 \\
8 & MS-5 & $1.55-1.75$ & 30 \\
9 & MS-7 & $2.08-2.35$ & 30 \\
10 & Pan & $0.48-0.69$ & 10 \\
\hline
\end{tabular}

${ }^{\star}$ Spectral bands in addition to the current Landsat bands.

been the highest priority in the Park's resources management program (Andrascik 1994), and control of leafy spurge infestations, in particular, has become a primary resources management issue at Theodore Roosevelt National Park.

Prior to 1993, ground estimates of leafy spurge were delineated on topographic maps. In 1993, the Agricultural Research Service (ARS) mapped the leafy spurge infestation in Theodore Roosevelt National Park using visual photo interpretation methods using low-altitude aerial photographs (Everitt et al. 1995; Anderson et al. 1997). This interpretation identified over 700 ha of leafy spurge. This process produced a product that allowed park managers to utilize resources to control the infestation, but the mapping effort required extensive time and commitment. Beginning in 1994, biological control using insects began, with increasing insect releases over time. Landscapescale reduction in leafy spurge infestation has occurred in some areas; however, it is estimated that leafy spurge might now infest over 1800 ha of the south unit (National Park Service 2006). More automated techniques for monitoring the location and extent of leafy spurge, especially if available on a seasonal basis, would add greatly to the effectiveness of control measures.

The use of state-of-the-art remote sensing technology for detection and mapping of leafy spurge at Theodore Roosevelt National Park began in 1998 as part of a cooperative demonstration project between the National Aeronautics and Space Administration (NASA) and the United States Department of the Interior (DOI). It had already been shown that remote sensing could be an efficient and cost-effective method for measuring the percent cover of leafy spurge (Birdsall et al. 1997). The NASA/DOI Hyperspectral Technical Transfer Project (Root and Wickland 2001) demonstrated that leafy spurge could be identified and mapped through analysis of hyperspectral imagery using NASA's Airborne Visible and Infrared Imaging Spectrometer (AVIRIS) (O’Neill et al. 2000). Other imagery sources being tested for use in mapping leafy spurge include Landsat 7 ETM+, the Agricultural Research Service's Compact Airborne Spectrographic Imager (CASI) (Root et al. 2002), and NASA's Hyperion orbital imaging spectrometer on the Earth Observing-1 (EO-1) satellite (Root et al. 2002, 2003).

In addition to the Hyperion, the EO- 1 satellite also contains the Advanced Land Imager (ALI) sensor. This sensor was designed to provide comparable or improved Landsat spatial and spectral resolution with reductions in mass, volume, and cost. It operates in a pushbroom fashion, scanning along-track with a linear array, capturing the entire scan line at once like a pushbroom sweeps. Its spectral bands were chosen to mimic 6 current Landsat bands with 3 additional bands (Speciale 2002). Because of its additional spectral bands as well as its higherspatial resolution panchromatic band, it is hypothesized that the EO-1 ALI data might be useful for mapping the location and extent of leafy spurge infestations in Theodore Roosevelt National Park.

\section{MATERIALS AND METHODS}

\section{Study Area}

Theodore Roosevelt National Memorial Park was established April 25, 1947. It was redesignated in 1978 as Theodore Roosevelt National Park. Over the years there have been multiple boundary changes, and in 1978 the Park designated 12109 ha as wilderness. The Park currently consists of 3 separate units totaling 28498 ha. Management of the Park emphasizes protection and interpretation of the badlands ecosystems surrounding the Little Missouri River and the cultural resources resulting from human habitation of the area.

Leafy spurge arrived in North Dakota in the early 1900s, carried by homesteaders (Lym et al. 1998). It has invaded a large number of counties throughout much of the United States. It was first reported in Theodore Roosevelt National Park in the late 1960s (Andrascik 1994; Anderson 1995). By 1993, leafy spurge infested 550 ha of the Park, principally within drainage channels and creek and river bottoms (Anderson 1995).

\section{Image Processing}

A cooperative demonstration project between NASA and the DOI began in 1998 to test state-of-the-art remote sensing technology for detection and mapping of leafy spurge at Theodore Roosevelt National Park. As a part of this project, EO-1 satellite data were collected. The ALI sensor aboard the EO-1 satellite was designed to provide data comparable to or improved from Landsat spatial and spectral resolution. It collects data within spectral bands chosen to mimic six current Landsat bands and three additional bands (see Table 1). Its spatial resolution was also chosen to mimic Landsat providing 30-m multispectral imagery but with a panchromatic band at $10-\mathrm{m}$ resolution.

All image classification was ultimately done in ENVI 3.6 (Research Systems, Inc., a wholly owned subsidiary of Eastman Kodak Company, Boulder, CO), although georeferencing point collection and initial processing tests were carried out in earlier versions of ENVI.

ALI data were collected on 6 July 2001, in association with Hyperion data. This imagery was received in Hierarchical Data Format by the USGS Rocky Mountain Mapping Center in 4 swaths running NNE to SSW across the landscape. Three of these swaths were required to cover the area of the south unit of Theodore Roosevelt National Park. The 3 swaths of 9 band, 30-m resolution multispectral data were merged into one file. Similarly, the 3 swaths of $10-\mathrm{m}$ panchromatic data were merged into a single file.

Band-by-band visual inspection revealed that there were a few anomalous vertical scans in bands 7 and 8 . These 
Table 2. Parameters used and accuracy of ENVI unsupervised ISODATA classification runs.

\begin{tabular}{|c|c|c|c|c|c|c|c|c|}
\hline Bands used & $\begin{array}{l}\text { Min. no. of } \\
\text { classes }\end{array}$ & $\begin{array}{l}\text { Max. no. of } \\
\text { classes }\end{array}$ & $\begin{array}{l}\text { Max. } \\
\text { iterations }\end{array}$ & $\begin{array}{l}\text { Max. } \\
\text { merge pairs }\end{array}$ & $\begin{array}{c}\text { Overall } \\
\text { accuracy }\end{array}$ & $\begin{array}{c}\text { User's accuracy } \\
\text { (spurge/not spurge) }\end{array}$ & $\begin{array}{l}\text { Producer's accuracy } \\
\text { (spurge/not spurge) }\end{array}$ & $\begin{array}{l}\text { Kappa } \\
\text { coeff. }^{1}\end{array}$ \\
\hline $1-10$ & 40 & 50 & 20 & 2 & $59 \%$ & $63 \% / 52 \%$ & $72 \% / 42 \%$ & 0.1386 \\
\hline $1-10$ & 50 & 75 & 55 & 4 & $64 \%$ & $64 \% / 62 \%$ & $84 \% / 36 \%$ & 0.2109 \\
\hline $1-7,9-10$ & 40 & 50 & 20 & 2 & $66 \%$ & $64 \% / 72 \%$ & $91 \% / 31 \%$ & 0.2372 \\
\hline $1-7,10$ & 40 & 50 & 20 & 2 & $62 \%$ & $65 \% / 56 \%$ & $73 \% / 46 \%$ & 0.2004 \\
\hline
\end{tabular}

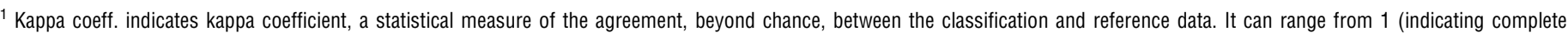
agreement) to -1 (indicating complete disagreement). A positive kappa indicates that the observed agreement is greater than chance agreement. The low kappa values were related to

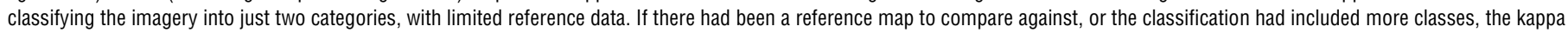
values probably would have been higher.

anomalous data, if included in an unsupervised classification, would generate additional spectral classes characterized by the unique, but not natural, combination of spectral values in these bad scan lines. Because the algorithm for replacing bad scan lines was written for horizontal scan line replacement, bands 7 and 8 were rotated in ENVI 3.6 so that the anomalies were horizontal, and the anomalous scan lines were then replaced by averaging the neighboring scan lines. The bands were rerotated back to their original orientation and merged with the remaining multispectral bands.

One-meter resolution digital orthophoto quarter quads (DOQQs) were generated and mosaiced for the USGS from 1996 aerial photography. The mosaic was used as the reference image in the georeferencing process. The multispectral data and the panchromatic data were georeferenced separately. In each case, 11 pairs of points were chosen from the image set and the DOQQ, and a spatial subset of the ALI data covering the study area were georeferenced. The total root mean square (RMS) error was 0.4 pixel for the multispectral $30-\mathrm{m}$ georeference and 0.3 pixel for the panchromatic $10-\mathrm{m}$ georeference. The georeferenced 30-m multispectral image set was then resampled to $10-\mathrm{m}$ resolution using a nearest neighbor algorithm and combined with the 10 -meter panchromatic dataset creating a final 10 -band $10-\mathrm{m}$ dataset. This resampling of the multispectral data did not alter the spatial quality of the $30-\mathrm{m}$ data, but permitted the spatial precision of the panchromatic data to be incorporated into the classified results.

The 10-band 10-m dataset was then classified using ENVI's ISODATA unsupervised algorithm and 3 different band combinations. See Table 2 for the parameters for each run. For all runs, the change threshold was set at 5.00, the minimum number of pixels per class was set at 100, the maximum standard deviation was set as 1 , and the minimum class distance at 5 . The maximum standard deviation from mean and the maximum distance error were left unspecified, causing all pixels to be classified into one of the resulting classes.

The classifications were displayed with a simulated colorinfrared, color table based on the statistics for the mean reflectance values for each class in bands 7, 3, and 2. Each class was highlighted to visually compare its distribution with the grid cell field survey data (National Park Service 2001) and the 1993 map of leafy spurge distribution (Anderson et al. 1994, 1997; Everitt et al. 1995). Classes that appeared to follow the larger landscape patterns of invasion based on the older 1993 photo-interpreted map, as well as having representation within the area of grid field data known to have leafy spurge representation in 2001, were chosen for a first lumping.
As a separate technique for determining assignment to spurge/not spurge groupings, the number of pixels of each class falling within the area of leafy spurge grids was calculated. The classes with the largest number of pixels within the grid field data did not completely match up with the classes that were visually chosen. Using the pixel counts, the visual comparison was repeated and a few modifications to the chosen classes were made. This allowed some empirical statistics to be used within an essentially interpretive methodology in an attempt to increase the accuracy of the grouping of classes into a spurge vs. not-spurge map.

\section{Field Surveys}

During the summer of 2001, field crews at Theodore Roosevelt National Park conducted detailed ground surveys of major leafy spurge infestations. The goal was to characterize the presence and density of leafy spurge in spatial relation to the associated native vegetation. The sampling scheme was based on $32 \times 32 \mathrm{~m}$ grid cells, within which the percent cover of up to 29 vegetation types, including leafy spurge, was recorded (National Park Service 2001). These data were used as the basis for choosing the leafy spurge presence and absence classes from the unsupervised remote sensing classification results.

Field work was conducted from 1999 through 2001 to monitor leafy spurge response to chemical and biological control measures. Crown cover (via stem counts) and biomass of native vegetation and leafy spurge were collected from 550, $3 \times 5 \mathrm{~m}$ plots. The biomass was defined as the sum, in grams, of biomass on $3,0.25 \times 0.25 \mathrm{~m}$ subplots per plot. Locations of plots containing leafy spurge were chosen based on a combination of known biocontrol locations and stratified random samples from areas previously mapped as leafy spurge (Anderson et al. 1997). Plots not containing leafy spurge were randomly selected within a buffer zone extending $250 \mathrm{~m}$ from previously mapped leafy spurge infestations (Anderson et al. 1997). The 2001 spurge biomass data from this study were used as the basis for quantitative accuracy assessment of the leafy spurge map described in this study. If there was any spurge biomass in 2001, the plot was categorized as spurge; if there was no spurge biomass in 2001, the plot was categorized as not spurge.

\section{RESULTS}

The accuracy of each of these maps was tested against the biomass plot data (Anderson et al. 1997). Only 279 of the 550 plots actually were located within the area of the ALI scene and 


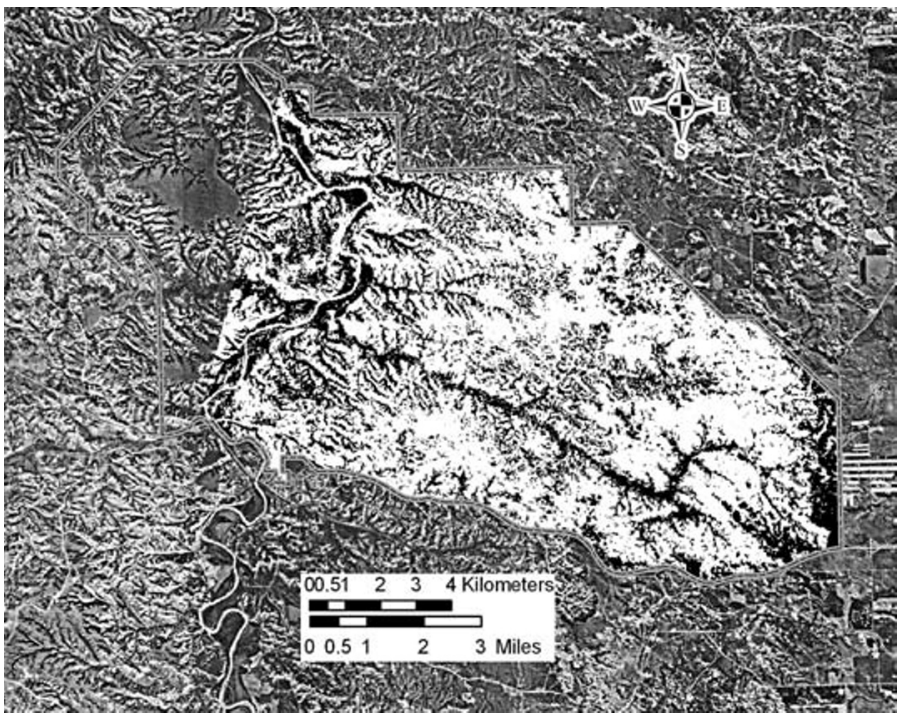

Figure 1. Leafy spurge distribution map derived from unsupervised ENVI ISODATA classification of E0-1 ALI bands 1-7 and 9-10 within the south unit of Theodore Roosevelt National Park.

were used for this analysis. The plot locations were converted to ENVI Regions of Interest and a confusion matrix was calculated. The accuracies of each set of band combinations are given in the last column of Table 2.

Inclusions of the mid-infrared band $8(1.55-1.75 \mu \mathrm{m})$ in the unsupervised classification did not improve leafy spurge discrimination, and in fact, reduced the accuracy of leafy spurge classification (Table 2). The best discrimination of leafy spurge was achieved using bands 1-7 and 9-10, arriving at an overall accuracy of $66 \%$.

In the maps generated from the various classifications of the satellite data, leafy spurge is confused with some agricultural crops on the far eastern edge of Theodore Roosevelt National Park (Fig. 1). If this technique is used to generate a regional map of leafy spurge distribution, then cropland should be removed from the map, or the distribution of leafy spurge will be greatly exaggerated. This did not affect the accuracy estimates of this map, as the Park was interested in leafy spurge surrounded by native plant communities within the National Park boundary, and thus no accuracy assessment points were located in agricultural areas.

\section{DISCUSSION}

Nine of the 10 bands going into this classification were based on 30-m pixels, with 1 band, the panchromatic, based on 10-m pixels. The difference between the image classification based principally on $30-\mathrm{m}$ pixels, and the accuracy data, collected on $3 \times 5 \mathrm{~m}$ plots introduces some image subpixel differences. Even if a $3 \times 5 \mathrm{~m}$ field plot contains no leafy spurge biomass, the $30 \times 30 \mathrm{~m}$ image pixel within which it is found could legitimately be classified as leafy spurge, thus creating some false errors. The reverse is also hypothetically possible, with a $3 \times 5 \mathrm{~m}$ field plot containing a single spurge plant, but the $30 \times$ $30 \mathrm{~m}$ image pixel within which it is found being legitimately mapped as not significant spurge. Although the field plots were lumped as having spurge or not having spurge, imagery pixels would logically have a threshold percentage of spurge cover before they are classified as "spurge." Because this study was designed to use existing data, this problem cannot be rectified. Ideally, the accuracy data should be gathered within the same spatial resolution as the data being classified.

Other studies have achieved higher overall accuracy results for mapping leafy spurge, but these have used hyperspectral data for increased spectral discrimination. Hyperion data, with 220 bands and 30-m resolution, was used to map leafy spurge in Theodore Roosevelt National Park with overall classification accuracies ranging from $63 \%$ using the Spectral Angle Mapper algorithm to $75 \%-78 \%$ for the red-edge spectral parameters and isoclass clustering algorithms (Root et al. 2003). AVIRIS data with 224 bands and 20-m pixels has been used to map leafy spurge with an overall accuracy reported at $87 \%$ (Parker Williams and Hunt 2004). A study using HyMap hyperspectral data with 126 bands and $3.5 \times 3.5 \mathrm{~m}$ pixel size, reported accuracies of $84 \%-94 \%$, notable, however is that this project incorporated buffering to deal with georegistration errors (Glenn et al. 2005). Forest One, Inc. reported overall accuracy of $88 \%$ for mapping leafy spurge using a 128 band tunable AISA EAGLE sensor and 2-m spatial resolution (Forest One, Inc. 2006). Although 66\% accuracy sounds relatively low, the mitigating factor related to the size of the accuracy assessment points allows for the possibility that the overall accuracy should actually be higher.

The EO-1 ALI sensor was part of a technology verification project designed to demonstrate comparable or improved Landsat spatial and spectral resolution for less weight, size, and cost. With the addition of more spectral bands than ALI, but perhaps not as many as a hyperspectral instrument, a next generation satellite might be able to accurately and relatively easily map invasive leafy spurge. With increased interest and money being invested in small satellites worldwide, there is a possibility that a new small satellite system might be developed with the capability for accurate leafy spurge identification. One existing small satellite is Proba, which was launched by the European Space Agency in 2002 with the Compact High Resolution Imaging Spectrometer (CHRIS) on board. CHRIS is a hyperspectral sensor that can image the earth at up to $18 \mathrm{~m}$ resolution in a combination of 19 out of 62 programmable spectral bands. This sensor, or its follow-on, Proba-2 to be launched in 2007, might be capable of accurately mapping leafy spurge for local land management needs.

\section{IMPLICATIONS}

The mapping of leafy spurge using EO-1 ALI data might be useful for illustrating the regional spread of leafy spurge over large areas, as this method had high producer's accuracy, (i.e., low omission errors). High producer's accuracy indicates that where there was leafy spurge on the ground, this method was able to identify it. This sensor could also be useful as a tool to stratify costly and intensive control efforts, because such a map could be used as an indicator of new areas of leafy spurge infestation at regional levels. However, this sensor is not likely to be extremely useful for local management and control efforts because of the relatively low overall accuracy of identifying leafy spurge. The overall accuracy was affected by the low user's accuracy (commission errors), which indicates that this 
method was identifying more leafy spurge than was actually on the ground.

\section{LITERATURE CITED}

Anderson, G. L. 1995. Using remote sensing and geographic information systems for mapping noxious weed infestations within North Dakota. In: Proceedings of the Alien plant invasions: increasing deterioration of rangeland ecosystem health symposium. Bureau of Land Management. BLM/OR/WA/PT-95/ 048+1792. p. 28-32.

Anderson, G. L., J. H. Everitt, D. E. Escobar, N. R. Spencer, and R. J. Andrascik. 1994. Mapping leafy spurge (Euphorbia esula) infestations within Theodore Roosevelt National Park using large format aerial photography and geographic information system technology. In: C. H. Schmidt (ED.). Proceedings of the leafy spurge strategic planning workshop, Dickinson, North Dakota. 29-30 March 1994. Fargo, ND: North Dakota State University. p. 42-56.

Anderson, G. L., J. H. Everitt, D. E. Escobar, N. R. Spencer, and R. J. Andrascik. 1997. Mapping leafy spurge (Euphorbia esula) infestations using aerial photography and geographic information systems. Geocarto International 11:81-89.

AnDRASCIK, R. J. 1994. A post workshop review: discussion, process, and highlights for developing a leafy spurge strategic management plan within Theodore Roosevelt National Park. In: C. H. Schmidt (ED.). Proceedings of the leafy spurge strategic planning workshop, Dickinson, North Dakota. 29-30 March 1994. Fargo, ND: North Dakota State University. p. 109-117.

Birdsall, J. L., P. C. Quimby, Jr., N. E. Rees, T. J. Svejcar, and B. F. Sowell. 1997. Image analysis of leafy spurge (Euphorbia esula) cover. Weed Technology 11(4):798-803.

Cogan, D. R., and J. L. Butler. 1999. Impacts of leafy spurge on local and sandscape patterns of plant species diversity in Theodore Roosevelt National Park. In: 1999 Leafy spurge symposium proceedings. Medora, North Dakota. 26-27 June 1999. Fargo, ND: North Dakota State University Cooperative Extension Service. p. 20-21.

Everitt, J. H., G. L. Anderson, D. E. Escobar, M. R. Davis, N. R. Spencer, and R. J. ANDRASCIK. 1995. Use of remote sensing for detecting and mapping leafy spurge (Euphorbia esula). Weed Technology 9(3):599-609.

FOREST ONE, Inc. 2006. Identification and Mapping of Leafy Spurge (Euphorbia esula L.). Internal Report. Forest One, Inc. Jackson, MS. 3 p.

Glenn, N. F., J. T. Mundt, K. T. Weber, T. S. Prather, L. W. Lass, and J. Pettingilll. 2005. Hyperspectral data processing for repeat detection of small infestations of leafy spurge. Remote Sensing of Environment 95:399-412.

LYM, R. G., AND R. K. ZoLLINGER. 1995. Integrated management of leafy spurge. North Dakota State University, W-866 (Revised), March 1995. Available at: http:// ndsuext.nodak.edu/extpubs/plantsci;weeds/w866w.htm. Accessed 19 May 2003.

Lym, R. G., C. G. Messersmith, AND R. Zollinger. 1998. Leafy spurge-Identification and control. North Dakota State University, W-765 (Revised), October 1998. Available at: http://ndsuext.nodak.edu/extpubs/plantsci/weeds/w765w.htm. Accessed 27 May 2003.

Mack, N. R., D. Simberloff, W. M. Lonsdale, H. Evans, M. Clout, and F. Bazzaz. 2000. Biotic invasions: causes, epidemiology, global consequences and control.
Issues in Ecology. Washington, DC: Ecological Society of America. No. 5, $20 \mathrm{pp}$.

MerRitt, S., D. HiRsch, and D. Nelson (compilers). 2000. Biological control of leafy spurge, a comprehensive, easy-to-read manual on how to use biological control as an effective leafy spurge management tool. Sidney, MT: USDA-ARS TEAM Leafy Spurge. $2^{\text {nd }}$ printing. Available at: http://www.team.ars.usda.gov/ aphisman.html. Accessed May 2006.

National Park Service. 1994. Recommendations for the management of leafy spurge in Theodore Roosevelt National Park. Medora, ND: Theodore Roosevelt National Park, Medora. $27 \mathrm{p}$.

National Park Service. 2001. Ground truthing remotely sensed leafy spurge infestations at Theodore Roosevelt National Park: methodology for mapping project using global positioning systems and geographic information systems. Internal Report. US Department of the Interior, National Park Service. Medora, ND: Theodore Roosevelt National Park. 6 p.

National Park Service. 2006. Theodore Roosevelt National Park silent invaders. Available at: http://www.nps.gov/thro/tr_exotic.htm. Accessed 6 May 2006.

O'Neill, M., S. L. Ustin, S. Hager, and R. Root. 2000. Mapping the Distribution of Leafy Spurge at Theodore Roosevelt National Park using AVIRIS. In: Proceedings of the $9^{\text {th }}$ Jet Propulsion Laboratory (JPL) airborne earth science workshop. University of California, Davis. Available at: ftp://popo.jpl.nasa.gov/ pub/docs/workshops/00_docs/2000Proceedings.zip. Accessed May 2003.

Parker Williams, A. E., and E. R. Hunt, JR. 2004. Accuracy assessment for detection of leafy spurge with hyperspectral imagery. Journal of Range Management 57:106-112.

Pimentel, D., L. Lach, R. Zuniga, and D. Morrison. 2000. Environmental and economic costs of non-indigenous species in the United States. BioScience 50:53-65.

Root, R., S. Ustin, P. Zarco-Tejada, C. Pinilla, R. Kokaly, G. Anderson, K. Brown, K. Dudek, S. Hager, and E. Holroyd. 2002. Comparison of Aviris and E0-1 Hyperion for classification and mapping of invasive leafy spurge in Theodore Roosevelt National Park. In: Proceedings of the AVIRIS earth science and applications workshop, 5-8 March 2001, Pasadena California: Jet Propulsion Laboratory. Available at: ftp://popo.jpl.nasa.gov/pub/docs/workshops/ 02_docs/2002Proceedings.zip. Accessed May 2003.

Root, R. AND D. WickLAND. 2001. Hyperspectral technology transfer to the U.S. Dept of Interior: summary of results of the NASA/DOI hyperspectral technology transfer project. In: Proceedings of the $10^{\text {th }} \mathrm{JPL}$ airborne earth science workshop. Pasadena, California. NASA Jet Propulsion Laboratory. Available at: ftp://popo.jpl.nasa.gov/pub/docs/workshops/01_docs/2001Proceedings.zip. Accessed May 2003.

Root, R., P. Zarco-Tejada, and C. Pinilla. 2003. Identification, classification, and mapping of invasive leafy spurge using Hyperion, AVIRIS, and CASI. In: Earth Observing-1 preliminary technology and science validation report, Part 3 , Section 30. Available at: http://e01.gsfc.nasa.gov/new/validationReport/ Technology/Documents/Tech.Val.Report/Science_Summary_Root.pdf. Accessed June 2006.

SPECIALE, N. 2002. Advanced land imager NASA. Available at: http://e01.gsfc.nasa. gov/Technology/ALIhome1.htm. Accessed 1 May 2003. 